\title{
ILLEGAL JOURNEY: THE INDONESIAN UNDOCUMENTED MIGRANT WORKERS TO MALAYSIA
}

\author{
Ridwan Wahyudi \\ Faculty of Social Sciences and Humanities, Universiti Kebangsaan Malaysia, Bangi, \\ Selangor, Malaysia
}

Correspondence: Ridwan Wahyudi (email: rwahyudi.bmi@gmail.com)

\begin{abstract}
The objective of this study is threefold. First, it uses fieldwork to explore the illegal journey of the Indonesian undocumented migrant workers, including all processes and interactions. Secondly, it identifies the substantive factors behind illegal influx into Malaysia. Thirdly, it draws out the implications from the illegal journey undertaken by them to Malaysia. This qualitative study applies the grounded theory approach. The result of this study shows that social capital within their network expands through various channels, particularly friendship, brotherhood, neighborhood, community and ethnic grouping. It also permeates strongly beyond government authority and regulation. They have constructed social classes among themselves. However, they have also been less able to get the social access because the absence of official documents deprives their human rights, and they are also blamed for social ills. Therefore, the regulation for both countries must recognize the rights, improvement governance, strengthen the integrity and curb corruption.
\end{abstract}

Keywords: corruption, Indonesian undocumented migrant workers, Malaysia, middleman, social capital

\section{Introduction}

As many 232 million people have migrated to the leading countries of the world. From those numbers, 71 million happened within intra-Asia and included 14 million migrant workers in ASEAN (ILO, 2014). The number of migrants is rising by 2030 and it is estimated that there will be about 30 million in ASEAN. Even the issue of migrant workers has rendered a vagueness regional relation between the countries of ASEAN, particularly Indonesia and Malaysia (Pandu, 2007). Destination countries of migrant workers include Malaysia, Singapore,
Brunei, and Thailand and origin countries include Cambodia, Indonesia, Laos, Myanmar, Philippines and Vietnam (Migration News, 2013). Malaysia is one of the largest importers of migrant workers for various sectors within the Asia Pacific region, alongside Singapore, South Korea, Japan, Taiwan and Hong Kong. Although the participation of women in the workforce is conspicuous, there is still a need for migrant workers to suffice certain sectors (Ducanes, 2013). These sectors include both semi-skilled and low skilled jobs most importantly plantation, manufacturing, service, construction, and domestic workers 
(ILO, 2014). Ministry of Home Affair (MoHA) of Malaysia said that more than 2.25 million people held temporary work permits in 2013 (MEF, 2014). The World Bank (2015) estimated that there were undocumented migrant workers in Malaysia more 1 million in 2014.

The majority of migrant workers perform low skill workers, such as cleaners, farm workers, construction workers, drivers, waiter, and so on. The prominent of work performed by migrant workers that categorized as 3D (Dirty, Difficult and Dangerous) (ILO, 2014; Human Rights Watch, 2004). Based on the statistical data from National Agency for Placement and Protection of the Indonesian Overseas Workers (BNP2TKI), 429,872 migrants in 2014 and 275,736 in 2015 have been flown out to abroad. During the same time period, 127,827 and 97,635 migrant workers left for Malaysia, respectively (BNP2TKI, 2016). The Malaysian Government have prior enacted policies, such as the clearance entry at the border, increasing the payment for working visas, detaining undocumented migrant workers, promoting local workers to work in sectors that have been employed by migrant workers, supporting employers to employing local residents, and utilizing technology to reducing the mass labor (Marhani, et.al., 2012; Mohamed, et.al., 2012; Yusof, 2005). Nevertheless, these policies have been unable to reduce the influx and dependence on migrant workers, due to lack of technical implementation and the most employer have still relied on the services of migrant workers, particularly low skilled workers (Kanapathy, 2004; Mei, 2006).

Indonesian migrant workers have frequently entered to Malaysia Peninsula through the routes of Batam and Johor Bahru (Castles, et. al., 2014; Hugo, 2005). IOM mentioned that immigration restrictions and border controls in Southeast Asia have led to human trafficking and people smuggling (IOM, 2011). Undocumented migrants have chosen and routed illegal channels to escape from being detected by immigration authorities of both countries, in terms of irregular migration. Furthermore, IOM (2015) noted that within period 2005-2014, victims of trafficking from Indonesia amounted to 7,193 people. Unfortunately, as the media highlights, hundreds of people within the period of 20142016 died while trying to travel between Indonesia and Malaysia (Fadli, 2016; The Jakarta Post, 2015; Jatmika, 2014; Masrur, 2014). Therefore, this study firstly explores the processes and interactions that happened during the journey of undocumented Indonesian workers to and from Malaysia. Secondly, this study identifies factors that stimulate Indonesian undocumented migrant workers to enter Malaysia illegally. Thirdly, it draws out the implications from the illegal journey undertaken by Indonesian undocumented migrant workers to Malaysia.

\section{Literature Review}

There are several of debates about international migration. Therefore, the phenomenon of international migration could be seen from multidisciplinary academics, such as sociology, political science, law, economics, demography, geography, psychology and cultural studies (Brettel and Hollified, 2015). However, the most prominent and enormously influential theory is the international migration introduced by Lee (1966) which describes a push and pull model of migration. Moreover, at the latest notion, migrant workers have been not solely focused on men, but also women attracted by income and employment opportunities (Ducanes, 2013; Elias, 2008) and who are driven to improve the lives of their families in their 
country of origin (Castles, et.al., 2014; IOM, 2005; Hugo, 2005). Meanwhile, Indonesian migrant worker push factors include poverty, unemployment, wage differentials, weak legal system implementation, ease of counterfeiting identity documents of migrant workers, and the lack of coordination between ministries or agencies involved. The pull factors are easy to penetrate the Malaysian immigration, cultural and religious similarities, access transport system, a wide-open job opportunity and a lack of oversight enforcement agencies (Prayitno, 2015; ILO, 2014; Mei, 2006).

A recent debate is related to the issue of social capital as accounted by Castles, et.al. (2014). According to Lin (2002), a social network is an investment for expecting a return. It involves individual and community networks (Bourdieu, 1986; Coleman, 1988; Putnam, 1996) including network system of migrant workers by Morowska (2007). According to Boyd and Nowak (2012). there are four patterns of migrant networks: kinship networks, private networks, and network employees and a network of undocumented workers. This network is the consolidation process in the context of migrant communities (Zetter, et.al., 2006) and interdependence between each other (Rudiger and Spencer, 2004). When there is a grievance, undocumented migrant workers asked for assisting from family members, neighbors, friends, relatives and other social institutions to provide aid and better economic opportunities. The same thing takes place among Indonesian migrant workers in Malaysia would tie to closest to the countryman network (Hasanah, 2015).

\section{Definition of Undocumented Migrant Workers}

Kasim and Mat Zin (2011) have categorized undocumented migrants into eight categories. First, a person who enters a country with travel documents (passport) and an official labor document, but the document is not renewed after expiration. Second, someone has a working visa officially, but works elsewhere i.e. employer name different from the place where he/she works. Third, a person who enters a country with only a travel documents (passport) and abuses the consent by working in the country. Fourth, someone who does not have any travel documents (passport) when entering a country. Fifth, the children born in Malaysia are not officially registered by parents abroad. Sixth, foreign people have different identity documents than the identity of the document holder. This is counterfeiting and document fraud. Seventh, they are asylum seekers, refugees where Malaysia is not a signatory to the Convention of Refugees, 1951/New York, 1967. Eighth, refugees in Sabah were given permission to stay temporarily under a special pass, which can be renewed every year. If not renewed, the refugees are considered informal settlers.

\section{Research Methodology}

This study employs qualitative by using grounded theory approach. It means that the approach has a constructivist perspective to build from scenario and series of occurrence experienced by the researcher (Charmaz, 2006). Furthermore, I depict the findings of my experience of the illegal journey by focusing on myself as the primary source. This was also explained by Pace (2012) in applying analysis strategy through grounded theory where researcher him/herself is used as the primary source in data collection. Grounded theory avoids the hypothesis and supposes to the theory that referred by the researcher, with the result in coming from the original sources were collected from observing and in the field script for analyzing the occurrences (Peters, 
2014; Pace, 2012). Analysis technique is based on the sources of transcription through open coding, axial coding, theoretical memos, selective code and constant comparison (Pace, 2012; Creswell, 2009; Charmaz, 2006).

I traveled with undocumented Indonesian migrant workers directly as they started the travel from their hometown in Sampang and transited to Surabaya and Batam (Indonesia), then entered Malaysia via Johor Bahru and ended at a construction site. I also interviewed five Indonesian undocumented migrant workers and a senior diplomat of the Embassy of Indonesia as a complementary data from observations. I also observed sixteen Indonesian undocumented migrant workers in their group which comprise of three people of the employer as the head of migrant workers, a foreman, an agency of documentation, a ferry company in Batam, two employers of Malaysian citizen (sub-contractor company owner) and the main contractor company. The survey took for about sixteen months, i.e. in the period 2014-2015.

\section{Result Study}

\section{A. Findings}

\section{(1) Character, Life and Tradition}

In summer, people usually plant tobacco, if they have sufficient capital to cultivate it. For those people who do not have the capital, the unproductive land is left unoccupied and without the crop. Water for bathing, drinking and planting is rare during the dry season. I look at that brain drain phenomenon has been acutely occurred in Madura Island. Many residents have migrated to all corners in Indonesia and abroad. Consequently, there are a limited number of residents in this area. Madura Island population, which on average, are a senior citizen and they always rely on their children and relative at overseas. They consistently remit to their parents and relatives at the village. I testified that Madurese have had been less enthusiastic against practicing of farming as much land remain idle and unproductive. Although they do not work, their children and relative overseas consistently meet the need to them for everyday life.

Madurese have preserved their traditions. During the day, they spend a time to work and either to chat with the whole family in a place called by taneang lanjeng at night. Taneang lanjeng is the Madurese traditional house and used for praying, such as tiny mosque (surau/ musaola) as well. Every family ought to have a surau at home in Madurese tradition and it is located on the outside of principal house building and available a yard amid the row of the relative house. Sometimes, they also put in a television inside the corner of surau. After praying, they would watch to television and chat to each other with their whole family till getting sleepy coming.

Most people have supposed that Madurase constitute a rude tribe. However, it actually is stigmatization that labeled to them. The term carok is a common thing in Madura. Carok is a fight between the Madurese with the incisive sickle. Death or serious injury rendering defects is genuineness within the carok. This is why the others look at Madurase as harsh compared to other Indonesian ethnicities. Occasionally, Madurese take it into the best solution and it signs to Madurese dignity. Afterwards, carok is the best way of life in the Madurese ethnicity if they are insulted to three key points of life. Rochana (2012) mentioned that there have been three heritages that ought to be guarded and respected for Madurese value, which are women, tanean lanjeng and jobs. Any interference and threats affecting the values of Madurese would lead 
to carok. For Madurese, jobs definitely give meaning for everything because barrenness of the land has driven them to its value. This is why Madurase geography is typically labor ethic rather than land ethic even if compared with their Javanese sibling.

Family left behind who have migrant just returned usually run a feast for their safety while in abroad. All relatives and neighbors are invited to enliven the kenduri (ritual Moslem party tradition). Not just a feast alone, but migrant member families always bring some gifts to be distributed to relatives and neighbors. The gift is representing the value of social interaction among Madurese. The worth of gift would imply for the recognition and respect from neighbors of the family of the migrant. This activity is a symbol of motivation for success migrants. Even they would be willing to buy luggage on the plane to put some gifts distributed. They did not mind though in the process they looking for money and working were huge of risks and challenges in Malaysia. The most important thing for them is the recognition of the status, the honor of relatives and neighbors gathered after the re-integration with the environment. After spending remittance at the village, remigration preparation is the next step one to looking forward to this cycle.

\section{(2) Documentation for International Migration}

A little of Madurese migrant have demographic documents, such as identity cards, family cards, a birth registration and education certificate. These documents are as a prerequisite for citizens of Indonesia to have a passport. They have been accustomed to acquiring those documents in various ways whether procedurally or not procedurally. Many of them do not have complete documents and some even have a fake identity. To obtain the documents, they have to surreptitiously bribe officers through the middleman. The high cost is not an obstacle to them because there are tekong (unregistered recruitment agent/middleman) who bail out of all the costs by over borrowing pattern. The loan should be paid off by migrants after entering Malaysia and working at there. Tekong is a middleman who he/she usually also has a role as the employer in Malaysia. Middlemen and migrant group would try to hide that they are leaving the village for Malaysia. This is to avoid police raids or operations within the journey. Basically, they have realized what they doing is illegal thing, even though they do not know what the migration procedural is. Information on labor migration has been clogged and unable to be reached by the migrant. Nevertheless, local officials have also been less cooperative and would immediately take action against those who transgress of the falsification. Labor migration procedure was stipulated and compelled by the states through recruitment agencies which highprice for the migrant worker.

\section{(3) Journey to Surabaya}

I together with a group of migrants departed from the village on Friday, September 18, 2015. It had been done after their morning prayers (subuh) with different vehicles and time in each group. The police usually carry out checks along the way, for example in the Surabaya-Madura Bridge. Police would inspect to documents of people who want to travel abroad. Cops often get confidential information from tekong too. Tekong reports to police that there are migrants who were on a trip to entering Malaysia illegally. Tekong assists and bears the expense of making the identity card, family card, passports and airfare. For smoothing any matters, tekong frequently 
charges for additional costs as giving bribes to officer. Tekong also frequently intimidate and threaten the migrants. I accompanied a migrant in processing a passport issuing at the Pamekasan immigration office which saw that tekong paid IDR1 million ( \pm US\$ 70) to officer in order to smooth the passport processing. The passport fee is only IDR355 thousand $( \pm \cup S \$ 25)$.

\section{(4) The Border Circumstances}

During transit in Batam, this was a sorrowful stage for migrants. All migrants had to sit the room without enough room to stretch his legs. None could sleep comfortably, let alone lied down with a pillow. The proper accommodation was too expensive for them. They just sat and relaxed by lying down onto an unused box. There was only one bathroom to be used by hundreds of people. This building was smelly and dark with insects and trash strewn everywhere. Migrants were threatening and occasionally reminded not to talk too loudly because there were a lot of police outside the building. After entered into the building, we were locked inside the building by tekong. We could not pray in the absence of water and being surrounded by feces. Water pipe worked from 1 am until 4 am in the morning, afterwards, there was no water supply. Migrants could survive with such a precarious condition, even among them had occupied until a week.

\section{(5) Tekong (the Middleman)}

Tekong who accompany of migrants journey was actually connected to the tekong in Batam. He is who managed all entry for migrants to Malaysia. They must pay to tekong in Batam. It thus yields to be a wealthy man. He has an unused metal collector companies in Batam and also invests some stocks for one of Airline Corporation as well. He usually buys an unused large ship to be unpacked and resold of the iron. He has certainly a partner with government officer at the border in Batam to carry out migrants' influx illegally. He has been providing service of thousands of migrants into Malaysia illegally for every month. No wonder he has been able to provide for IDR1.2 billion ( \pm US $\$ 90,000$ ) per month to be paid to officer in Indonesia and Malaysia. His employees always apply to vary of methods and tricks to approve the entry of migrants, including bribing the officer. His charge had several differentiations to migrants. For those who have the blacklist, they must pay RM700 ( \pm US\$ 165) and RM300 ( \pm US\$ 75) for the first entering to Malaysia. After bribing to officer through the tekong, then the sheets of passport that were stamped by Malaysia immigration staff must be removed by tekong. Immigration staff is unavailable to be responsible for his decision to allow an entry permit to someone who actually is banned by the government. This pattern was actually presented by McMurray (2001) which argued that the border area with various features official borderlines is the real perpetrator border smugglers or human trafficking. It has been happened to the people of Mexico and Guatemala to the United States. Even Hagan (2008) instead mentioned the border official as more appropriate as the actual robbers.

(6) After passing off the Borders Clandestinely

To have undocumented status in Malaysia is not a serious problem for Madurese as long as they have a countryman network, any problem can be resolved by the network. Access to health facilities, housing, shopping, clean water, jobs and social relations with local residents are not difficult for them. There 
have formed a social class between the workers and the head of workers who are able to manage and maintain of the labor. Even, when migrants cannot operate a computer for supporting their work, they would ask internet shops to assist migrants in term of solving any administration works. Many Indonesian migrants actually have their own business in Malaysia but under the name of a local resident. They have become employer for other migrants. They have dealt with local residents through a consensus for commission every month so that their business runs smoothly. The employers have been actually dependent on the supply of labor that he had brought from the village illegally.

Almost all the workers who live in rumah kongsi (shared house) are the undocumented migrants' worker. Rumah kongsi are semi-permanent house inside of on-going construction site. They are not only comprising of immigrants from Indonesia, but also from Bangladesh, India, Vietnam and others blending inside it. Sometimes, rumah kongsi are located deep inside the forest to safeguard the security of migrant workers against a police raid or the authorities. Placement far away from local communities and unexpected places inhabited by humans potentially avoid detection by the authorities. Social relationships within the rumah kongsi of migrants have been tied up in harmony, assisted to another and complemented each other.

\section{(7) The Employment of Undocumented}

There is an assortment of construction jobs for Indonesian migrant workers in Malaysia. They are particularly working on scaffolding, plastering, welding, bricklaying, painting, ceiling, and finishing, maintaining, as well as general labor. At the construction site, the foreman is usually Indonesian and he/she oversees dozen undocumented migrant workers. Several foremen have joint cooperation with Malaysian employers and register the company on behalf of a Malaysian resident. They establish a sub-contractor company for supplying chain of labor to the main contractor in construction commerce. As a foreman, he/she recruits new labor and the prioritize relatives, neighbors, or people of the same ethnicity, which is Madurese. The kinds of employment Madurese have included scaffolding, maintaining, farrier, and staging. Plastering, ceiling, painting and finishing are done by Javanese people.

There is no certainty regarding about when undocumented Indonesian migrant workers would return to their home country. Nevertheless, they could return at any time they want to, if necessary. They have found a way to get home safely without receiving punishment from the Malaysian government for violating the residency permit. If they have been also caught by the Immigration Department during the raid, they would be charged by the Malaysian law on article 36 of the Immigration Act 1959/63, which was amended in 2006 stipulated that a person who has been found guilty of entering or staying in Malaysia over the period will be fined not more than RM10,000 ( \pm US $\$ 2,325$ ) compounds or imprisonment not exceeding five years or both and also the names she was sentenced to whipping not exceeding six strokes. Concurrently, such undocumented migrant workers are not willing to undergo the punishment for immigration violations.

\section{(8) Legalization Policy for Undocumented}

There were a series of policies issued by the government from 2011 to 2015 in order to control illegal immigration. This 
included registration, amnesty, legalization, surveillance, enforcement, and deportation or commonly known as the 6P (Program Pendaftaran, Pengampunan, Pemutihan, Pengawasan, Penguatkuasaan dan Pengusiran). Afterward, these programs have been converted into rehiring program or $3 \mathrm{P}$ for short (Program Perekrutan dan Penggajian Semula) that ran from February 2016 to December 2016. These programs were implemented by private companies appointed by the MoHA of Malaysia. Consequently, undocumented migrant workers must pay a fine to the government and the cost of such services to private companies.

Iman Resources Company is an agency that assigned by the MoHA to implement $6 \mathrm{P}$ in 2014. A similar program was developed by MoHA 2011-2014. However, many agencies involved within program in 2011-2014, even MoHA argued that it is hard to oversee and monitor such agencies. Thus, MoHA only assign single agency. I could contact with middlemen when arrived at the company's car park at Iman Resources Company. They offer a variety of added value if we apply their services, ranging from freight aircraft, sequential numbers, for faster treatment and others. The involvement of middleman would implicitly increase the cost of management for those who follow the program. Compared to a prior policy through in which undocumented migrant workers just paid RM400 ( \pm US\$90) for fine at immigration department before in 2011, with the implementation of that program, Iman Resources Company increased the cost to a total of RM923 ( \pm US\$210) in 2015 for undocumented migrant workers who followed the voluntary repatriation program. It also did not include the ticket fare, where each undocumented migrants had to purchase it to Iman Resources Company as well. Fare purchasing from outside agencies was not allowed by Iman Resources Company. The cause is the only Iman Resources Company knowing the schedule of the returnees. Its reason is that Iman Resources Company just does not want a mistake to serving its customer, even though this is somewhat a monopolistic practice. Meanwhile, ticket fare is more expensive than prices in other agencies. Between August and December 2014 , as many as 29,126 people registered joining this program. And between January and May 2015; 21,787 people returned home through Iman Resources Company (Prayitno, 2015). It is an enormous value for a guilty pool if its number is converted to the nominal value.

B. The Factors of Undocumented Migrant Workers

Based on the findings, there are two factors explaining on why undocumented migrant workers are willing to transgress the challenging and risky Malaysian border. These factors include economic factors and socio-legal factors. With regards to economic factor, migrants need jobs and revenue by considering the wage difference between countries of origin and destination, as mentioned by Massey, et.al. (1993). However, economic factor is divided into two stages, the micro and meso levels. Micro level leads to a deeper personal or motivational aspect regarding undocumented migrant workers who are willing to undergo such a precarious condition. In addition, the migrant has shown that the micro level to encourage them have agreed to make the decision to migrate out of the personal context. Sometimes economic factor at micro level can emerge as encouragement or insistence from family, neighbors, relatives, friends, or family relationship. Meso level has looked at deeply concerned into a network of undocumented migrant workers that are also 
encouraging someone decision to migrate with undocumented status. Meanwhile, Houg (2008) argued that social network is embodied the form of kinship, friendship, and ethnic demarcation among fellow undocumented migrant workers.

Economic interests are the dominant factor behind why undocumented migrant workers decide to migrate (King, 2012; Massey, et.al., 1993). Their will is to always have a better livelihood and opportunity on the future. It based on the desire and motivation aspect for a better livelihood that is created through deed. In fact, the desire aspect is indefinite promise for a reality. Personal desire is also influenced by environmental conditions of migrants including family, ethnic demarcation, the closest relatives, neighbors and environmental factors of the migrants. They look at environment from the perspective of interaction and always refer to the value of surrounding environment, particularly in terms of property ownership. It is the sign a reference to the belief migrants' on deterministic materialism. Then they always think that migration to Malaysia would always bring up for better livelihood. This desire is based in turn on generating the will and realized into deed to migrate.

Migrants who failed also always have produced the genuine face on the environment. Most of failed migrants are deported by the Malaysian government for not having documents. This shows the failure observed by its environment; sensing very embarrassed is experienced by migrants because of its environment labels as individuals who fail from abroad. Perception is disclosed solely by the individual fails, even though the environment does not consider as such. The personal perception appears in line with the value of environment in which refers to the failure. The actual perception is subjective. In another word, the society is not necessarily to judge that migration can assure for a better life to the truth value. Instead, this understanding is contagious as the correct sense by migrants and continues trusted by migrants. Each trust generated the will become an action that led to the migration. Thus, at the near future, they are ready to re-migrate and leave their home.

Environmental sphere drives to things of the deterministic materialistic (Lefebvre, 2009). This has been considered by a former migrants who has been successful. Success status improves the interaction process with their sphere. The sophisticated technology of property that had will affect the other migrants to follow the successful way. Therefore, the consciousness to comply the regular migration requirements fades, although undocumented migrant workers know the risky and challenging of illegal journey. Furthermore, the sphere has spawned an external desire of consciousness through the conspicuous asset. Thus, undocumented migrant workers deed has conscious unconsciousness of the decision to migrate (Morowska, 2007). They are not thinking that migration abroad has many obstacles, risks and challenges. Their desire is based on a value in society showing a sign of recognition that must be achieved. The recognition of their status in society is also the abstract things. It is just experienced by the individuals who are affected by the subjective evaluation. Similarly, with regard to the status of sphere is an integral part of value contained within the migrant communities.

Meso-level is concerned with the relationship of network within undocumented migrant workers. As has been stated above that their goal is to obtain a value that is based on asset, whether concrete or abstract. To achieve it, they must be involved with the network of undocumented migrant workers. 
Meso-levelis concerned withadhering interplay with the micro-level (Houg, 2008). Members in a social network of migrants depend on each other. Moreover, social network is not only to overcome financial matters, but also to cover their affairs in Malaysia. Interaction involves the interplay between subjects into a social network. Each individual involved within the network of undocumented migrant workers would always think that he/she is going to lead the group legally or illegally. The status of migrants will also consider to the person who has carried into Malaysia. They will scour the truth of people involved to carry into Malaysia. In this context, the respondents were chosen by the researchers came from the same village. That is, between tekong and person who recruits have known one another. This process gives rise to a truth that tekong is a person who has been trusted to manage the safe migration. Furthermore, tekong is a person who is successful in terms of economic and asset that were obtained from overseas. This becomes an additional contribution to increasing the truth that inherently had by tekong.

The truth value is going on the intersubjectivity relationship within the network led to a sustained and robust system (Muadz, 2014). The truth is also influenced by cultural aspects and a clear demarcation between individuals within the network. This aspect will greatly strengthen the system within the network of undocumented migrant workers; despite their practice are illegal things. The goal of the network is required by entering into Malaysia and worked up earning at abroad. Tekong who role as an employer for undocumented migrant workers also has the responsibility to achieve those goals. This is different things in such of a tekong generally. Tekong usually only, for instance, treat as providing assistance to undocumented migrant workers to enter the area of Malaysia. It means that he/she is just solely pro fitoriented. However in this context, tekong who also a role as the employer in Malaysia has the responsibility for the safety of all its labor, whether in passing off the border security within journey and safety while working in Malaysia with an illegal status.

The value conceived within a network of undocumented migrant workers is the will of inter-subjectivity. All members within a network have the same goal which is to enter and work in Malaysia illegally. It is stated at the mesolevel that before beginning an action, every subject must have the will. Despite the status of undocumented migrant workers is not to their penchant, but the limited information, to be a victim of fraud and high costs to be documented workers are a matter that cannot be resolved by tekong or even employer itself. Thus, the undocumented migrant workers are extremely complicated option that must be chosen by them. Their will is to improve the living and future, it is not a solely desire to undocumented status. Nevertheless, to be documented migrant workers constitutes their desire. Likewise, at last, to be undocumented migrant workers is their will. This was seen when they did not want to document their status even they actually have money and access to do it. Therefore, to change the undocumented status become documented must instill a way of thinking in which every individual will be able to. Each of individual will definitely have implications for action (Muadz, 2014).

The truth value, the will value and the love value within a network of undocumented migrant workers would not be achieved if there are no other factors that influence undocumented migrant workers, which is the communication between individuals within the group. Communication within network system 
of migrants has reached three of which have been mentioned above. Even so, I argued that foreman or employers who recruit migrant from the same village, seen very dominate within a network. Employer of undocumented migrant workers also developed other networks for expanding access required by all members within a network. Network communication power that had by migrants leader is decisive to dominate within a network. Access in this term is with respect to access to seeking jobs in Malaysia, access to other middlemen including all of its employees illegally to Malaysia, access to arrange for the returning of migrant workers illegally to the village. The role of middlemen who is as foremen or employer strengthens its position within the network group of undocumented migrant workers.

The socio-legal approach is basically the legal approach which is applied to social sciences widely (Irianto, et.al., 2012). However, in this discussion is to present the social phenomenon happening to undocumented migrant workers that are closely linked with existing regulations for migrant workers. Although this study has methodological framework itself, but it showed the relationship between the two sets through the analysis conducted in this survey. This provides an overview of law involved to do the job by migrant, as not only the normative approach between right or wrong. These factors are determined by considering the history of migration between Indonesia and Malaysia. Presentation of social aspect is discussed in greater depth about the conditions applicable to existing migration regulation, both of migration in Indonesia and Malaysia.

Regulations are available and stipulated by governments of both countries to manage labor migration. However, there is a question for purposes of existing rules already covers aspects of social progress by migrant workers, particularly for undocumented status. If referring to each process, migration is a long chain that involves the countries of origin and destination of migrant workers. In addition, it is found that the two countries have a same root history and culture, but the rules do not seem to recognize and pay attention to the two aspects. Therefore, I argue that there is a conflict between social phenomena and laws. Effects of the two countries have governed migration with the private sector for management of migration leading populous Indonesia migration to Malaysia independently and informally (Killias, 2010).

The basic needs are not only involved in the needs of food, clothing and housing, but it also includes the safety of individuals, access to communication and information, environment, justice, freedom and social aspects felt by undocumented migrant workers while working. These factors are also very influencing to migrants out of their home areas in Madurese people to Malaysia. Social access is the rights of the human. However, inequity development in Indonesia involves difficult to reach the social access. Therefore, the basic needs is the rights of every individual to be completed by employer and government. In fact, become undocumented migrant workers are not the main choice of a person, but rather a necessity for the precarious condition at their hometown in gaining the social access (Cormoş, 2014).

Network manages every precaution to reduce the authority of investigation and raid. The usual pattern of their practice is to collect money from all undocumented workers. The funds are usually collected and handed over to the foreman of such sector. Further, the fund is stretched to the head of construction site work. Head of labor at a construction site is usually a citizen who came from Indonesia. $\mathrm{He} / \mathrm{she}$, then, grants money to the authorities. 
There is a fricative in respecting of safety for undocumented migrant workers. Individual safety for migrants is obtained by criminal way for committing acts of corruption to the authorities. This term is used by groups of undocumented migrants in gaining safety access to work.

\section{The Implication of Undocumented Migrant Workers}

Discussion of social class on society was not only focused on the sociology, where it had been dominant models of social classes. As has been described by scholars, Knap, et.al. (2005) had discussed the manner than with a chance of life, while Robert and House (2000) discussed about health, illness and death, as well as Svallfors (2006), gave an opinion on the social classes in political behavior, Weeden (2002) and Grusky and Weeden (2008) also discussed social behavior. However, in recent discussions of social classes have been hovering on the socio-economic dimension, especially regarding the division of labor. In fact, the latest debate discussed social classes' dimension of migrant workers (Rogaly, 2014).

Indonesian undocumented migrant workers in Malaysia have been structured and divided into social classes that based on the situation and the work environment. This includes jobs as the employer, labor head, clerks, skilled workers, semi-skilled and low skilled workers. This case has been going on construction sector workers. These things have affected the involvement of values and norms prevailing among migrants. Value is referring to income and confidence generated from intimate social networks. The social class of undocumented migrant workers also affects the distribution of ethnic identity within the workforce. It is related to certain types of work into the construction sector. Seems to have a clear boundary demarcation is concerned with the skills of labor.

There is a long history of international migration between Indonesia and Malaysia (Liow, 2003). It has led to the consolidation of ethnic acculturation and could be felt up to now (Hugo, 2005b). Furthermore, it can be said that between Indonesia and Malaysia are the same race. This thus facilitates the consolidation process, cultures acculturation and ethnic interaction in line with daily activities. This term is no exception to building a social class of undocumented migrant workers in Malaysia. More precisely, social networking between people of Indonesia and Malaysia has been awakened strongly and prosperously. In fact, social network has been established outside the government authority to both of countries. However, then, both countries do not concern on the historical experience and the recognition of cultural migration to making the regulation. There is a migration process occurred outside of the legal framework through independence migration, but it has been instead declared to illegal things. The migration process, however, has been happening before the rules were made by the two countries. This is in line with the practical commercialization of law-making on migration management in Indonesia (Bactiar, 2013). This statement coincided with Castles, et.al. (2014) notion that there has been a connection with the international migration between Indonesia and Malaysia, in which occurred with the network of middlemen role. Although Indonesian government has had a policy on management of migration through a recruitment agency, but that has indeed legitimated to be exploitation way to migrant workers by states. As we know that, employment by using recruitment agency has emerged the high-price for recruitment fees 
whose burden to migrant workers (Killias, 2010).

Among the reasons for sustainability of undocumented migrant workers network are inherent resources owned by the middleman. The resource is the power of capital, attitudes and behaviors that are believed by undocumented migrant workers. Communication power and symbols of the prosperity that is owned by middleman also part of additional factors to strengthen the role of middleman within a group. Activities of middleman with various sources that he/ she had and practiced continuously have formed a group structure unwritten among the group of undocumented migrant workers. Integrity plays a role in assisting and creating the will of undocumented migrant workers to take the lead and provide a better life goal, also part of survival effect. Therefore, Lin et al. (2001) argued that inherent resources and network location are used as the factors that influence and at the same time as a measure the strength of a social network.

In this context, undocumented migrant workers have indicated that they have blamed the governments of both countries because they assume that the governments have always complicated to people for seeking a better life. In this situation, undocumented migrant workers have actually been experiencing the sense of conscious unconsciousness. The strength of network structure involves awareness towards undocumented migrant workers. Network structure has treated to undocumented migrant workers in the same way, although by oppression and extortion patterns on them. This situation has been happening constantly which cause them are not aware if they have been suppressed by the actor/middleman. This reality is a social phenomenon has been described by Morowska (2007) relating to the concept of structuration by Giddens that adapt to the international migration phenomenon involving the actors and structuring role.

Functions can be described as a passage to all components within a system. The system is none other than to act as a social network system of undocumented migrant workers. Based on the survey, I identified some social networking functions migrant workers are such as opportunities in seeking jobs for better life, providing financial, transportation and accommodation during the trip, dealing with the authorities to overcome the problems and information facilitation. Even the network role is more than government services that should overcome the grievance and protect migrant workers, including undocumented migrant workers.

Furthermore, each undocumented migrant worker for a certain construction site must pay the safety cost for such as staff RELA (Malaysian volunteer civil corps/paramilitary) and local police who usually worth range RM50 to RM100 ( \pm US\$11 to US\$22). In addition, the position of RELA are embodied by regulations $4 \mathrm{~A}, 4 \mathrm{~B}$ and $4 \mathrm{C}$ of the Immigration Act 2002 (amended), composed from civil, have made and added a long list of repression to undocumented migrants in Malaysia (Department of State US 2013). RELA has also taken the opportunity to insecurity condition from undocumented migrant workers in Malaysia, especially on migrant voting strategy for victory in elections rigged by the ruling coalition parties like the Barisan Nasional (National Front). Undocumented migrant workers used as a political tool to strengthen the authorities RELA opposition coalition of opposition parties (Kudo, 2013).

The legalization policy for undocumented migrant workers through rehiring program that held by Iman Resource Company can be said to have failed. Hence, there are not 
many migrants who pursue the program and continuously with undocumented status if comparing the amount of undocumented migrants in Malaysia. The problem lies in the requirements that it cannot be fulfilled by migrants. Meanwhile, such requirements have to comply as those living in Malaysia with undocumented status of more than three months based on immigration records, have no criminal footprint, have passed the medical examination, the permit fee borne by the employer, the employer's verification, employment agreement and the employer itself who must register it. If one of the stage cannot be met, afterwards, it is declared failed and migrants have to be deported to Indonesia. This elimination system leads migrants reluctant to join the legalization program. In addition, few employers who are willing to register directly, even though the cost of the permit is paid by the migrant themselves.

Many of the migrants try their luck through the broker's services. However, it is very risky for trying to manipulate it as if the broker has a role his employer. Likewise, the consequence that must be borne is the cost incurred higher than the certain cost because there is fee for brokers. Another problem lies with the employers of migrant workers who are not Malaysian citizens, but Indonesians who have settled in Malaysia for a long time. Indonesians like this usually cooperate with Malaysians to establish the enterprise or labor outsource. However apparently Malaysians do not know anything about employment, the most importantly Malaysians just earns a commission. On the other hand, the type of outsourced labor employer is often not granted by MoHA due to several considerations, namely based on liquidity, solvency, and profitability ratios. Therefore, the employer who considered feasible is the main contractor company. Unfortunately, this type of employer does not employ low-skilled migrant workers with manual exertion, but high-skilled jobs such as engineers, accountants, architects and other white-collar workers.

Overview of the relationship between the government of Indonesia and Malaysia has agreed that liberalization of migration management is more focused on the role of private sector with privatization model. Despite the implementation policy has been never mentioned explicitly, but the practice is visibly very significant. Privatization means the transfer of three components, namely the responsibility of the government, property (with or without obligation) or rights to the use of assets and human resources; to all obtained through the private sector (Sheshinski and Lopes-Calva, 2000). Indeed, privatization has certain practical purposes, which include liberating the financial burden of government, improving the work becomes more efficient and more productive, economic growth, reducing the rate and the presence of public sector economic activity and meeting the New Economic Policy (NEP). NEP has two main objectives of combating poverty desires without depending on the community and reorganize society to establish the identity of the economy at the future (Ling and Sing, 2007). If observed, migration management is not things that it is right or wrong but to focus on potential conflicts of interest. It limits the ability of government power and influence power to do good values in accordance with the principles of the rule, can be lowered and a commercial perspective and gain (Suraiya and Ahmad, 2011).

The actual implementation of above can be attributed to rent-seeking model. Term rentseeking activities give to exploit government resources for personal gain. Rent seeking is rather than the act of creating wealth but it 
benefited from the opportunities who created by others (Brou and Ruta, 2011). In the general view, rent seeking is negative in which frequently considers the ineffectiveness and inefficiency as the individual divert resources from productive activities for their respective interlocked and related activities and holding power (Aidt, 2016). Hence, if the rent seeking is not controlled, it will result in corrupt behavior and the centralization of power is governed and influenced by a specific person ( $\mathrm{Ng}, 2006)$.

There has been no long-term policy conducted by the Indonesian government to reduce the influx of undocumented migrant workers to Malaysia. In reality, the route of undocumented migrant workers has been definitely identified by the government. However, corruption and unauthorized collaboration have taken place at the border point by officers to both of countries, even though it conceives the characterization of the diversity this special monitoring unit. Thus, it was true that the border officers are the real criminal actor by Khosravi (2010).

\section{Conclusion}

Migration between Indonesia and Malaysia have begun before independence (Kaur, 2005: 4-5). Political tensions between the two countries relating to migrant workers have marked since the early 1980s. Indonesian undocumented migrant workers have to comply with the law in Malaysia (Prayitno, 2015); and then Indonesian should improve on labor migration management. Migrant workers should also be aware of the necessary documents and immigration Indonesia should be more careful in issuing passports. Transgression of migration procedures and corrupt practices by middlemen needs to be controlled and enhanced efforts to curb. The
Indonesian government also should focus on equal development in rural areas so that more job opportunities, particularly in the area of origin of migrants. Accordingly, independent migration in Indonesia, in term of the condition without private sector involving, should be regulated soon by the government to give an option to people rights on free movement.

The strategy undertaken by the Malaysian government by tightening visa application charge for migrant workers should be reviewed. Accordingly, the Malaysian government has to oversee private foreign recruitment company for imposing high fees to migrant workers in completing the employment provision. Hence, many undocumented migrant workers have become victims of fraud and racketeering by the middleman, actor who suspected as an individual civil servant and police. Consequently, levy imposed on migrant workers cannot afford to pay because complexities of management and obscurity procedures. Precisely, it also contributes to the undocumented migrant workers that not willing to register themselves. This is also in line with giving the strict sanction by the Malaysian government to employers who employ the undocumented migrant workers. In addition, the dissemination of information and streamlining management for legalization undocumented migrant workers have to be accomplished by Malaysian government. Accordingly, eradication corruption must be enforced for every institution that provide services for migrant workers in Malaysia.

Sophisticating of middleman in communication to migrant workers develops the robust network. The social network takes place on an on-going basis and habitually. At last, more migrant workers believe the role of middlemen despite overruling the law. The situation prevails in line with the statement by Giddens in structuration theory 
as a condition of conscious unconsciousness. In these circumstances, a person's ability to acquire awareness becomes blurred, making it difficult to think rationally to follow the formal channels (Morowska, 2007). Networks of undocumented migrant workers have established social relationships among labor. However, the ability, the strength, transparency and labor management is an important aspect that determines social class among undocumented migrant workers (Rogaly, 2014). Furthermore, a network of undocumented migrant workers has also created social classes based on the worker's occupation and ethnic specialization in which come from Indonesia. Undocumented migrant workers are always working to improve the ownership of such valuables, property, homes, vehicles, land, jewelry and status. The mark is very valuable to transforming the welfare of migrant workers in their life. Each of them is willing to bear the cost or sacrifice to gain riches which can be witnessed by the people around him (Lefebvre, 2009). Stimulation of the materialistic environment, encourage migrant workers are working together to achieve success even had to sacrifice anything and are willing to hazard risk for undocumented work in Malaysia.

\section{References}

Aidt, Toke S. 2016. Rent Seeking and the Economics of Corruption. Cambridge Working Paper Economics, 1621. Cambridge: The University of Cambridge. Bachtiar, Palmira Permata. 2013. The Governance of Indonesian Overseas Employment in the Context of Decentralization. Jakarta: SMERU Research Institute.

BNP2TKI. 2016. "Data Penempatan dan Perlindungan Tenaga Kerja Indonesia tahun 2015." Accessed at April 15, 2016, at $12.45 \mathrm{pm}$, http://www.bnp2tki.go.id/ $\mathrm{read} / 11034 / \mathrm{Data}-P e n e m p a t a n-d a n-$ Perlindungan-TKI-Periode-Tahun-2015. html.

Bourdieu, Piere. 1986. "The Forms of Capital." In John G. Richardson, eds. Handbook of Theory and Research for the Sociology of Education, edited by, 241-58. New York: Greenwood Press.

Boyd, Monica. and Joane Nowak. 2012. "Social Networks and International Migration" in Martiniello, M. and Rath, eds. An Introduction to International Migration Studies. Page 79 - 106. Amsterdam: Amsterdam University.

Brettel, Caroline B. and James F. Hollifield. 2015. Migration Theory: Talking Across Disciplines. New York: Routledge, Taylor \& Francis Group.

Brou, Daniel., and Michele Ruta. 2011. "Rent Seeking, Market Structure and Growth." Journal of the European Economic Association, Vol. 9 (6): 1143 - 1167.

Castles, Stephen., Hein de Haas., and Mark J. Miller. 2014. The Age of Migration: International Population Movements in the Modern World $5^{\text {th }}$ (fifth) Edition. New York: The Guilford Press, A Division of Guilford Publication, Inc.

Charmaz, Kathy. 2006. Constructing Grounded Theory: A Practical Guide Through Qualitative Analysis. London: Sage Publication.

Coleman, James S. 1988. "Social Capital in the Creation of Human Capital." American Journal of Sociology (94): 95-120, http:// www.jstor.org/stable/2780243.

Cormoş, Viorica Cristina. 2014. "Mentality and Change in the Context of International Migration." Procedia - Social and Behavioral Sciences, Vol. 149: 242 - 247. DOI: https:// doi.org/10.1016/j.sbspro.2014.08.224. 
Creswell, John W. 2009. Qualitative, Quantitative, and mixed Methods Approaches (3rd Edition)." Thousand Oaks, CA: Sage Publication, Inc.

Ducanes, Geoffrey. 2013. Labour Shortages, Foreign Migrant Recruitment and the Portability of Qualifications in East and South-East Asia. Bangkok: International Labour Office (ILO). http://www.ilo.org/ asia/publications/WCMS_226476/lang-en/index.htm.

Elias, Juanita. 2008. "Struggles over the Rights of Foreign Domestic Workers in Malaysia: The Possibilities and Limitations of 'rights talk'." Economy and Society, Vol. 37(2): 282 - 303. DOI: http://dx.doi. org/10.1080/03085140801933330.

Fadli. 2016. "18 Joint Investigation Conducted to Find Cause of Batam Boat Accident." The Jakarta Post, Accessed at December 16, 2016, at $2.36 \mathrm{pm}$ http://www. thejakartapost.com/news/2016/11/07/jointinvestigation-conducted-to-find-cause-ofbatam-boat-accident.html.

Grusky, David B., and Kim Weeden. 2008. "Are There Social Classes? An Empirical Test of the Sociologist's Favorite Concept". In Dalton Conley and Annette Laureau, eds. Social Class: How Does it Work? Page: 65 - 92. New York: Russell Sage Foundation.

Hagan, Jacqueline Maria. 2008. Migration Miracle: Faith, Hope and Meaning. Cambridge: Harvard University Press.

Hasanah, Tunira. 2015. "Potential Social Capital of Indonesian Immigrant in Malaysia: A Preliminary Research." Procedia - Social and Behavioral Sciences, Vol. 211: 383 - 389.

Houg, Sonja. 2008. "Migration Networks and Migration Decision-Making." Journal of Ethnic and Migration Studies, Vol. 34 (4): 585 -605. DOI: 10.1080/13691830801961605.
Hugo, Graeme. 2005a. Migration in the AsiaPacific Region. A paper prepared for the Policy Analysis and Research Program of the Global Commission on International Migration, Geneva, September 2005.

Hugo, Graeme. 2005b. Migrants in Society:

Diversity and Cohesion. A paper prepared for the Policy Analysis and Research Program of the Global Commission on International Migration, Geneva, September 2005.

Human Rights Watch. 2004. Abuses against Female Migrant Domestic Workers in Indonesia and Malaysia. July 2004 Vol. 16, No. 9 (B). Irianto, Sulistywati., Jan Michiel Otto., Sebastian Pompe., Adriaan W. Bedner., Jacqueline Vel., Suzan Stoter., and Arnscheidt Julia. 2012. Kajian Sosio-legal. Transleted by Tristam Moelyono. Denpasar: Pustaka Larasan.

International Labour Office (ILO). 2014.

Triangle Project: Practical Guidelines for Employers on the Recruitment, Placement, Employment, and Repatriation of Foreign Workers in Malaysia. ILO Bangkok.

International Organization for Migration (IOM). 2005. World Migration: Costs and Benefits of International Migration. Geneva: International Organization for Migration. International Organization for Migration (IOM). 2011. Counter Trafficking and Assistance to Vulnarable Migrants. Geneve: International Organization for Migration Annual Report of Activities.

International Organization for Migration (IOM) Indonesia. 2015. "Laporan Korban Perdagangan Orang tahun 2015." Jakarta: IOM Jakarta.

Jatmika, A. 2014. "Jumlah WNI Korban Kapal Tenggelam Jadi 14 Orang." Tempo. Accessed at November 2, 2016, 5.23 pm https://m.tempo.co/read/ news/2014/06/20/118586637/jumlah-wnikorban-kapal-tenggelam-jadi-14-orang. 
Kanapathy, Vijayakumari. 2004. International Migrationand LabourMarketDevelopments in Asia: Economic Recovery, the Labour Market and Migrant Workers in Malaysia. Paper prepared for the 2004 Workshop on International Migration and Labour Markets in Asia organized by the Japan Institute for Labour Policy and Training (JILPT) supported by the Government of Japan, Organisation for Economic Cooperation and Development (OECD) and the International Labour Office (ILO).

Kasim, Azizah and Rugaiyah Mat Zin. 2011. "Irregular Migrants and the Law." Philippine Journal of Development. 70 (38): Numbers 1 $\& 2$.

Kaur, Amarijit. 2005. "Indonesian Migrant Workers in Malaysia: from Preferred Migrants to 'last to be hired' Workers." Review of Indonesian and Malaysian Affairs, vol. 39 (2): 3-30.

Khosravi, Shahram. 2010. 'Illegal' Traveller: An Auto-Ethnography of Borders. New York: Palgrave Macmillan.

Killias, Olivia. 2010. "Illegal" Migration as Resistance: Legality, Morality and Coercion in Indonesian Domestic Worker Migration to Malaysia." Asian Journal of Social Science 38: 897-914.

King, Russel. 2012. Theories and Typologies of Migration: An Overview and A Primer. In Willy Brandt Series of Working Papers in International Migration and Ethnic Relations, edited by Erica Righard, 3/12. Malmo: Malmö Institute for Studies of Migration, Diversity and Welfare (MIM).

Knap, Bojan., Jadranka Buturovic-Ponikvar., Rafael Ponikvar and Andrej F Bren. 2005. "Regular Exercise as a Part of Treatment for Patients with End-stage Renal Disease." Therapeutic Aphresis and Dialysis, Volume 9, Issue 3, 211-213. DOI: 10.1111/j.17749987.2005.00256.x.
Kudo, S. 2013. "Securitization of Undocumented Migrants and the Politics of Insecurity in Malaysia." Procedia - Social and Behavioral Sciences, 17: 947 - 956.

Lafebvre, Henry. 2009. Space, State and World. Minneapolis: The University of Minnesota Press.

Lee, Everett S. 1966. "A Theory of Migration." Demography, Vol. 3 (1): 47-57.

Lin, Nan. 2002. Social Capital: A Theory of Social Structure and Action. New York: Cambridge University Press.

Lin, Nan., Karen Cook., and Ronald S. Burt. 2001. Building a Network Theory of Social Capital. New Jersey: Transaction Publisher.

Ling, Shum Yoke., and Yap Tet Sing. 2007. "Role of Government and Its Agencies in Promoting Industrialization." In Har Wei Mun, eds. Malaysian Economic Development: Issues and Debates. Kampar: Universiti Tunku Abdul Rahman

Liow, Joseph. 2003. “Malaysia's Illegal Indonesia Migrant Labour: In Search of Solution." Contemporary Southeast Asia, Vol. 25 (1): $44-64$.

Malaysian Employers Federation (MEF). 2014. Practical Guidelines for Employers on the Recruitment, Employment and Repatriation of Foreign Workers in Malaysia. Bangkok: ILO Asia Pacific.

Marhani, Mohd Arif., Aini Jaapar., and Nor Azmi Ahmad Bari. 2012. Lean Construction: Towards Enhancing Sustainable Construction in Malaysia. Procediasocial and Behavior Sciences, Vol. 68: 87 - 98. DOI: https://doi.org/10.1016/j. sbspro.2012.12.209.

Massey, Douglas S., Joaquin Arango., Graeme Hugo., Ali Kouaouci., Adela Pellegrino., and J. Edward Taylor. 1993. "Theories of International Migration: A Review and 
Appraisal." Population and Development Review, Vol. 19 (3): 431-466. Stable URL: http://www.jstor.org/stable/2938462.

Masrur. 2014. "Kapal Angkut 27 TKI Tenggelam di Perairan Malaysia." Tempo, Accessed at November 3, 2015, 8.45 pm. https://m.tempo.co/read/ news/2014/06/19/118586493/kapalangkut-27-tki-tenggelam-di-perairanmalaysia.

McMurray, David A. 2001. In and Out of Morocco: Smuggling and Migration in a Frontier Boomtown. Minneapolis: University of Minnesota Press.

Mei, Lin. 2006. Indonesian Labor Migrants in Malaysia: A Study from China. ICS Working Paper No. 2006 - 11. Kuala Lumpur: Institute of China Studies, Universiti Malaya.

Migration News. 2013. "South East Asia: ASEAN 2015." Migration News, Accessed at October 2013, Vol. 20, (4). Online version: https://migration.ucdavis.edu/mn/ more. php? $\mathrm{id}=3868$.

Mohammed, Ramesh Kumar Moona., Charles Ramendran., and Peter Yacob. 2012. "The Impact of Employment of Foreign Workers: Local Employability and Trade Union Roles in Malaysia." International Journal of Academic Research in Business and Social Sciences, Vol. 2 (10): 530 - 541.

Morowska, Eva. 2007. International Migration:

Its Various Mechanisms and Different Theories that Try to Explain it. Willy Brandt Series of Working Papers in International Migration and Ethnic Relations 1/07. Malmö: Malmö University.

Muadz, Muhammad Husni. 2014. Anatomi Sistem Sosial: Rekonstruksi Normalitas Relasi Intersuyektivitas dengan Pendekatan Sistem. Mataram: Institut Pembelajaran Gelar Hidup.
$\mathrm{Ng}$, D. 2006. "The Impact of Corruption on Financial Market." Managerial Finance, Vol. 32, (10): $882-836$.

Pace, S. 2012. "Writing the self into research: Using grounded theory analytic strategies in autoethnography." In Nigel McLoughlin \& Donna Lee Brien, eds. TEXT Special Issue: Creativity: Cognitive, Social and Cultural Perspectives. April 2012.

Pandu, Mario. 2007. Non-Traditional Security Issue and International Conflict: A case study of Indonesian Migrant Labor in Malaysia. MA Thesis, Lund University, Sweden.

Peters, I. 2014. Too Abstract to Be Feasible? Applying the Grounded Theory Method in Social Movement Research. Hamburg: German Institute of Global and Area Studies.

Prayitno, H. 2015. Tantangan Pelayanan dan Perlindungan WNI/BMI di Malaysia. This essay was presented by Indonesia Ambassador for Malaysia, Herman Prayitno, while receiving of Indonesia Senator (DPD RI) on May 21, 2015.

Putnam, R. 1996. "The strange disappearance of civic America." The American Prospect, Vol. (24): $34-48$.

Robert, Stephanie., and James S. House. 2000. "Socioeconomic Inequalities in Health: An Enduring Sociological Problem." Handbook of Medical Sociology, Vol. 5: 79 $-97$.

Rochana, Totok. 2012. "Orang Madura: Suatu Tinjauan Antropologis." Humanus Jurnal, Vol. 11 (1).

Rogaly, B. 2014. "Migration and Social Class: Insights from the New Mobilities Paradigm." Migration and Social Class Workshop on $2^{\text {nd }}$ April 2014, Department of Politic, Language and International Studies the University of Bath. 
Rudiger, Anja., and Sarah Spencer. 2003. Meeting the challenge: equality, diversity and cohesion in the European Union. Paper presented to the Joint European Commission/OECD conference on the economic effects and social aspects of migration, Brussels. Available on www.ippr. org.uk/research/files/team19/project22/ integration.doc.

Sheshinski, Eytan., and Luis F. lopes-calva. 2003. "Privatization and Its Benefit: Theory, Evidance and Challenges." CESifo Economic Studies, Vol. 49(3): 429 - 459. https://doi.org/10.1093/ cesifo/49.3.429.

Suraiya, Ishak \& Ahmad Raflis Che Omar. 2011. "New Paradigms of Corporate Social Responsibilities for Geovernment Linked Companies." Akademika, Vol. 81 (3): 75 81.

Svallfors, Stevan. 2006. The Moral Economy of Class: Class and Attitutedes in Comparative Perspective. California: Stanford University Press.

The Jakarta Post. 2015. "15 Indonesian Killed in Malaysia Boat Accident." The Jakarta Post, Accessed at April 4, 2016, at $7.43 \mathrm{am}$ http://www.thejakartapost.com/ news/2015/09/04/15-indonesians-killedmalaysia-boat-accident.html.

The World Bank. 2015. "Malaysia Economic Monitor, December 2015 - Immigrant Labour." The World Bank, Accessed at August 15, 2016, at $12.45 \mathrm{pm}$ http://www. worldbank.org/en/country/malaysia/ publication/malaysia-economic-monitordecember-2015-immigrant-labour. United Stated Department of State. 2013. Country Reports on Human Rights Practices for 2013: Malaysia. Washington: United States Department of State, Bureau of Democracy, Human Rights and Labor.
Weeden, Kim A. 2002. "Why Do Some Occupations Pay More than Others? Social Closure and Earnings Inequality in the United States." American Journal of Sociology, Vol. 108 (1): 55 - 101.

Yusof, Zakaria M. 2005. Ke Arah Pengurangan Kebergantungan Tenaga Kerja Asing di Sektor Binaan. Jurnal Alam Bina, Vol. 7 (2): $71-86$.

Zetter, Roger., David Griffiths., Nando Sigona., Don Flyn., Tauhid Pasha., and Rhian Beynon. 2006. Immigration, Social Cohesion and Social Capital. New York: Joseph Rowntree Foundation. 